\title{
The Effect of Self-awareness Rising on Identification and Accountability among High School Students
}

\author{
$\underline{\text { Soleiman YahyazadehJeloudar }}^{1}$, Shaban Hedarie ${ }^{2}$, Seyedeh Roghieh Mousavi Teroujeni ${ }^{3}$ \\ 1- Assistant Professor of Educational Psychology, in Department of women education \& Employment University of \\ Mazandaran, Mazandaran, Iran. ORCID: 0000-0001-9523-4050 E-mail: s.yahyazadeh@umz.ac.ir \\ 2- Assistant Professor of Islamic Azad University of Sarie Branch, Mazandaran, Iran. ORCID: 0000-0002-5053- \\ 7450 \\ 3- M. A. student of Islamic Azad University of Sarie Branch, Mazandaran, Iran.
}

Received: 08/06/2018

Accepted: 23/10/2018

\begin{abstract}
Introduction: Self awareness is one of the most important skills in one's life. It helps the person to better understand themselves and their characteristics, needs, feelings, and strong and weak points.

Aim: This study attempts to investigate the effect of self-awareness raising on identification and accountability among high school students.

Method: This study employs a pretest posttest semi-experimental control group design. The population of the study were all the high school second grade girl students in Sari city, District one $(\mathrm{N}=2878)$. The questionnaire about identity style and accountability was distributed among 200 of the participants. 30 students were selected using random sampling technique and divided into two groups of control (15) and experimental (15). The experimental group underwent 12 session of instruction. The ISI-6G identity style questionnaire and the California cognitive accountability scale (CPI) were used as data collection instruments. Data were analyzed using mean, standard deviation and co-variance analysis.
\end{abstract}

Results: Results have shown that self-awareness raising improves accountability and identification among high school students.

Conclusion: Results show that self-awareness raising can improves accountability and identification among high school students. Therefore, education authorities should attempts to take measures to improve self-awareness among high school students.

Keywords: Instruction, self-awareness, identification, accountability, high school student.

How to cite this article : Yahyazadeh Jeloudar S, Hedarie Sh, Mousavi Teroujeni S R . The Effect of Self-awareness Rising on Identification and Accountability among High School Students. Shenakht Journal of Psychology and Psychiatry. 2018; 5 (4): 52-62 .

URL :http://shenakht.muk.ac.ir/article-1-428-fa.pdf

Copyright (C) 2018 the Author (s). Published by Kurdistan University of Medical Sciences. This is an open access article distributed under the terms of the Creative Commons Attribution-Non Commercial License 4.0 (CCBY-NC), where it is permissible to download, share, remix, transform, and buildup the work provided it is properly cited. The work cannot be used commercially without permission from the journal. 


\section{اثربخشى آموزش خودآكاهى بر هويتيابى و مسئوليتيذيرى داشى آموزان مقطع متوسطه دوم}

\section{سليمان يحيى زاده جلودار'، شعبان حيدرى'، سيده رقيه موسوى تروجنى}

1. دكترى روانشناسى تربيتى، استاديار گروه يُزوهشى آموزش و اشتغال زنان دانشكاه مازندران، برديس دانشكاه مازندران دانشكده علوم انسانى و اجتماعى ،

مازندران، ايران. ايميل: S.yahyazadeh@umz.ac.ir

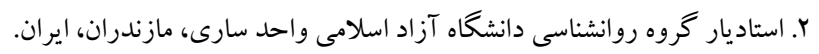
r. ك. كارشناسى ارشد رشته روانشناسى عمومى، مازندران، ايران.

مقدمه: يكى از مهمترين مهارتهاى زندگى، مهارت خود آكاهى است، اين مهارت به فرد كمكك مى كند تا بتو اند شناخت بيشترى

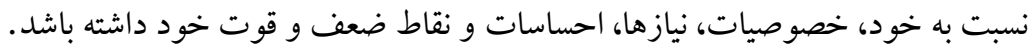
هدف: هدف يُزوهش حاضر بررسى اثربخشى آموزش خود آكاهى بر هويتيابى و مسئوليتيذيرى در دانش آموزان است. روش: روش ئزوهش نيمه آزمايشى با طرح بيش آزمون ـ بس آزمون با گروه كنترل بود. جامعه بِزوهش حاضر كليه دانش آموزان دختر مقطع متوسطه سال دوم ناحيه يكك شهرستان سارى بودند (N=rNVN)؛ كه يرسشنامهاى سبك هويت و مسئوليتيذيرى در ميان

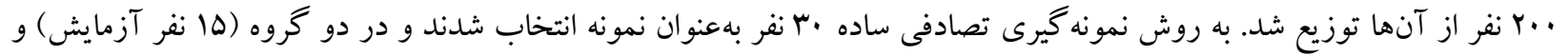

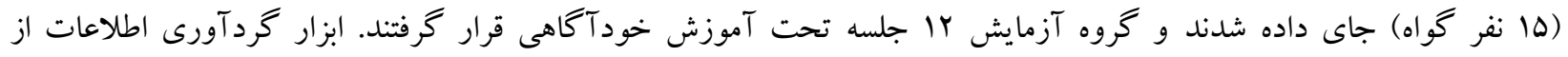

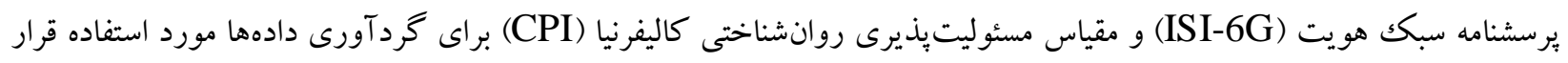

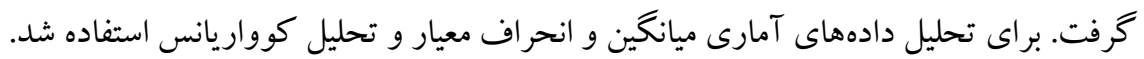

يافته ها: يافتها نشان داد آموزش خو دآكاهى باعث افزايش ميزان مسئوليتيذيرى و ايجاد هويتيابى در دانش آموزان شده است. نتيجه كيرى: نتايج نشاندهنده آن است كه آموزش خودآكاهى مى تواند بر مسئوليتيذيرى و هويتيابى در دانش آموزان اثر گذار

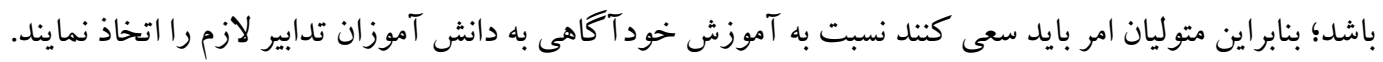
كليد وازه ها: آموزش؛ خود آكاهى؛ هويتيابى؛ مسئوليتيذيرى؛ دانش آموزان. 
ازجمله متغيرهايى كه با دوران نوجوانى در ارتباط تنگاتنك بوده و خودآكاهى نيز مىتواند بر آن اثر خذار باشد هويت است. بهطور اساسى در ايجاد يك زندكى

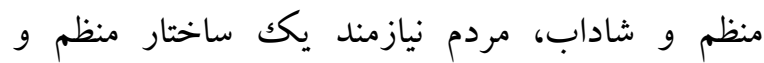
معنىدار در زندگى هستند كه شامل مهارتهاى حل مسئله، تصميم گيرى و تعبير و تفسير اطلاعات به شيوه خاص در زندكى مىباشند (برزونسكى بَّ و همكاران (Y. (Y). هويت و هويتيابى هم مسئلهاى تازهاى نيست و و به درازاى عمر بشر مطرح بوده و در هر برههاى از زمان و

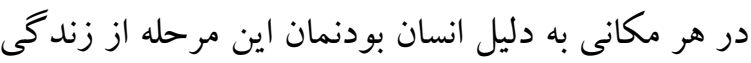
را خواهيم گذراند حال در زمانهاى دور شايد نامى ديخر بر روى اين مرحله از زندگى ناميده باشند. هويت جيزى نيست كه يككبار براى هميشه به كسى داده شده باشد، بلكه در طول حيات ساخته مىشود و تغيير مى كند. آن دسته از عناصر هويتها كه همراه با تولد ما به جهان مى آيند جندان زياد نيستند. بعضى خصوصيات جسمانى،

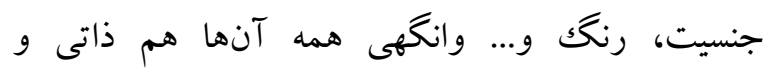
مادرزادى نيستند. اين برسش از آغاز تاريخ فلسفه يعنى زمانى كه سقراط كفت (خودت را بشناس) مطرح بوده و همه استادان به نحوى مطرح كردهاند تا به فرويد مىرسيم

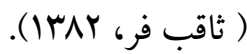

منظور از هويت همان ينداره فرد از خود است و از طريق آن، فرد به مفهوم يكهارجهاى از خود دست يِيدا مى كند و بر آن اساس در زندگى خود به قضاوت ارزشى مى بردازد

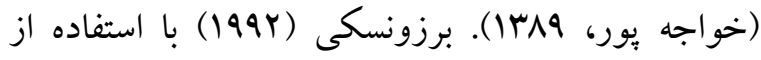
نظريه كنترل هويت، الكويى ارائه كرده است كه بر

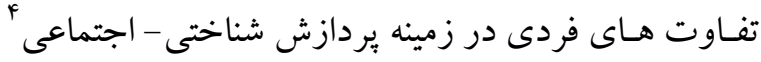

مقدمه

آكاهى از خود و خصوصيات مختلف خود، به انسان

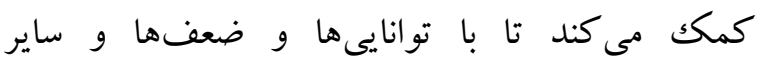
خصوصيات خود آشنا شود. همجنين در صورت برخورد با طرف مقابل و تشكيل زندگى مشتر كك بهتر و عميقتر با مسائل روبرو شود. اين خود آكاهى به شخص نشان

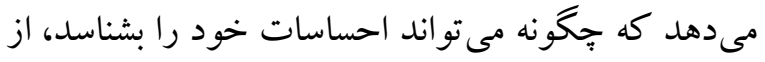
وجود آنها آكاه شده و به وقت لزوم كنترلشان نمايد تا منجر به هيج گونه ناراحتى نكردد.

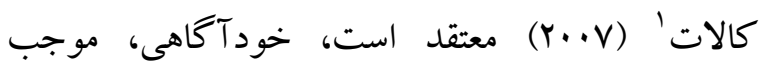
شناخت نياز افراد و يافتن راه مناسب براى مواجهه با آنها مىشود. همجينين اهداف زندگى را مشخصتر و واقع بينانهتر نشان مىدهد و ارزش واقعى افراد و مسائل "ير امونشان را نمايان مى سازد. (اخود آكاهى") تضمين كننده استحكام وجود فرد در هنگام بزرگكسالى است و و باعث يرورش روابط زن و شوهر در رويارويى با مشكلات و حل مناسب آنها مىشود. با آكاهى دادن به نوجوان و شناساندن آنان نسبت به خود مى توان فرد را با با بـ اتمام نقاط مثبت و منفى كه دارد آكاه كند جرا كه

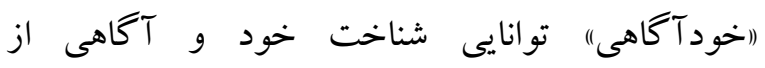
خصوصيات، نقاط ضعف و قوّت، خواستهها، ترسها و انزجارهاست. براى اكثر ما توصيف ويز گیىهاى اخلاقى و رفتارى خود براى ديخران، كار سخت و دشوارى است (سيدمحمدى، بوسا). خود آكاهى به اين معناست كه فرد جهه برداشتى از خود دارد و بر اساس اين برداشت جه

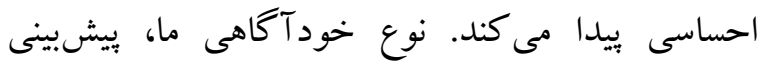
كنندهى احساس رضايت ما از خودمان و زندكى است

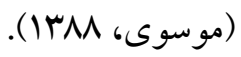

. Identity

3 . Berzoneski, et al.

${ }^{4}$. Social cognitive processing

${ }^{1}$.Kalat 
مسئوليتيذيرى(فعال و منفعل)، توسط سبكهاى متفاوتى از هويت بيشبينى مىشوند (جو كار و همكاران

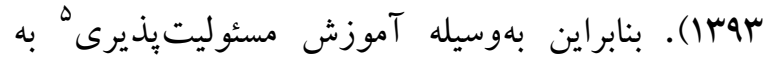
نوجوان مىتوان وى را براى ادامه يك زندكى مطلوب يارى نمود (رمضانى ديسفانى، ا9با). مسئوليت يا ليا مسئوليت يذيرى بهتنهايى، اشاره به حس وظيفهشناسى،

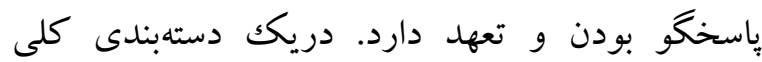
مىتوان مسئوليتيذيرى را به انواع: مسئوليتيذيرى در

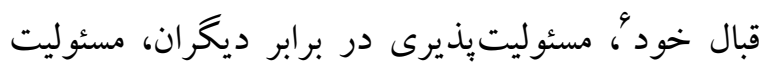
يذيرى در برابر خدا تقسيم كرد (طالبى و خوشبين •وسا). بجهها احساس مسئوليت را از والدين، مدرسه، دوستان و اجتماع مى آموزند و با آموختن اين مهارت با ارزش را تا آخر عمر حفظ كرده و اين امر باعث موفقيت بيشتر

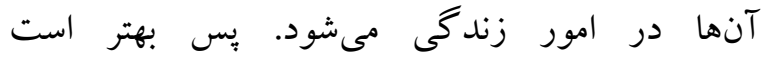

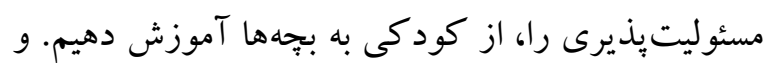
ازآنجايى كه جوامع در حال بيشرفت، نيازمند افرادى مسئول و خودكفا مىباشند، بنابراين انسانهاى امروز بيشازيش بايد مسئوليت زندكى و سرنوشت خود را

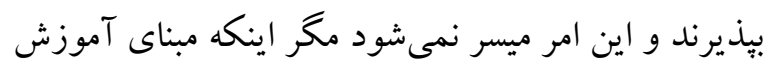
و يرورش مبتنى برافزايش دركك كود كان و نوجوانان در مورد نقش آنان در ساختن سرنوشت و كيفيت زندگىشان باشد و براى رسيدن به اين هدف سعى و كوشش و برنامهريزى دقيق لازم است. آموزش مسئوليت بذيرى به كود كان و نوجو انان كمكك مى كند كه احساس مسئوليت، شناخت و رفتار خود را بيذيرند و هم جنين بيذيرند كه خودشان مسئول سلامتى، موفقيت، ارتباط با ديخران و ارتباط با محيط هستند(بهرامى و

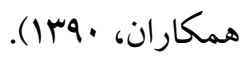

${ }^{5}$. responsibility

${ }^{6}$. Self- responsibility
نوجوانان در رويارويى يا اجتناب از سازماندهى' يـا بـاز سازماندهى مسائل مربوط به هويت تأكيد ميى كند. همجنين سماوى و حسين خارى (IrNV) در يُزوهش خود سوءمصرف مواد مخدر و بايگاه هويت را در دانشجويان بررسى كردند. نمونه اين يثزوهش .19 نفر از دانش آموزان بسر بودند. تجزيه و تحليل دادهها نشان داد كه هويتهاى تحميل شده و براكنده بيش بينى كننده مثبت و معنادار سوءمصرف مواد هستند و هويتهاى موفق و معوق نتو انستند سوء مصرف مواد را بيشبينى كنند.

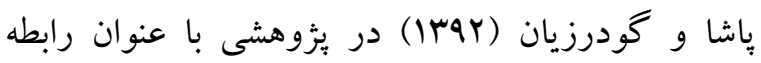
سبكهاى هويت و رشد اخلاقى با مسئوليتيذيرى

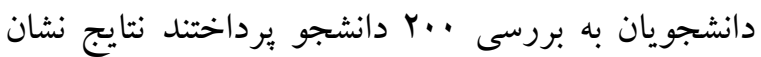
دادند كه بين سبككهاى هويت بيشرفته، مهلت خواه و رشد اخلاقى با مسئوليتيذيرى دانشجويان رابطه وجود

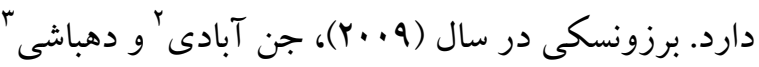
تأكيد نموده اند كه بين سبككهاى مختلف هويت (Y. F) و مسئوليت يذيرى ارتباط وجود دارد. متغير ديخرى كه مورد بحث در اين يزوهش است مسئوليت بِيرى است كه مىتواند با نوجوانى و بخصوص هويت نيز در ارتباط باشد. دورهى نوجو انى به سبب بروز مسائل خاص، بعضى اوقات با نوعى سردرگمى همراه با كاهش عزت نفس، خودكم بينى و خود يندارهى منفى همراه است كه سبب كاهش فعاليتهاى طبيعى و و تعاملات اجتماعى مىشود. يزوهشهاى اسكارتى،

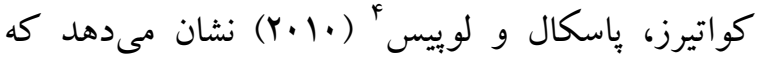
هو يت يابى با مسئوليت يذيرى ارتباط دارد. همبجنين يافتهها حكايت از آن داشت كه هر يكك از انواع

\footnotetext{
. Organization

2 . Jenaabadi

3. Dehbashi

${ }^{4}$. Escarti, Gutierrez \& Liopis
} 
بنفس در دانش آموزان شده است. طالبى و خوشبين

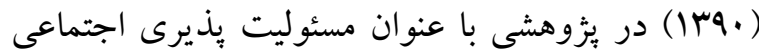
جوانان. به بررسى جوانان (وץ-·r) سال شهر همدان يرداختند. نتايج نشان دادكه ميزان مسئوليت يذيرى جو انان در ابعاد سياسى، اقتصادى و فرهنگى متفاوت است.

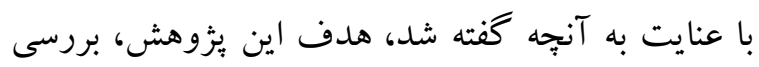

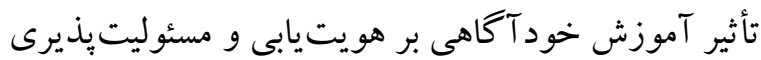
دانش آموزان مقطع متوسطه دوم شهرستان سارى است. در راستاى وصول به اين هدف، اين مطالعه در بى

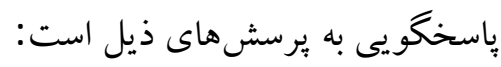

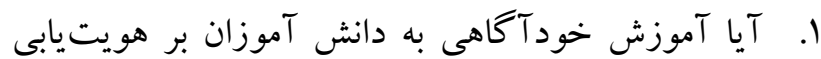

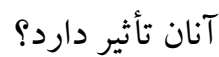

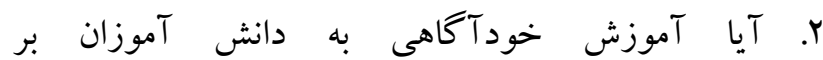
مسئوليت يذيرى آنان تأثير دارد؟ الئ

روش اين يُووهش بهصورت نيمه آزمايشى با بيش آزمون-

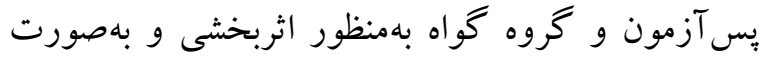
مداخلهاى انجام شد و به شيوه اجراى يرسشنامه بهصورت

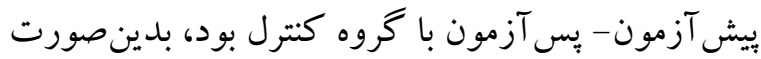

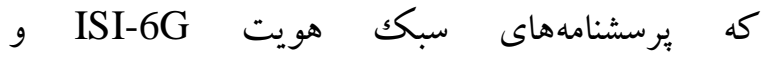
مسئوليت يذيرى ير سشنامه روانشناختى كاليفرنيا CPI در ميان دانش آموزان دختر مقطع متوسطه دوم شهرستان

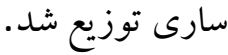
تعداد جامعه نهايى در اين تحقيق N =rAVA بوده كه از اين تعداد •r نفر از افراد بهصورت نمونه گيرى تصادفى

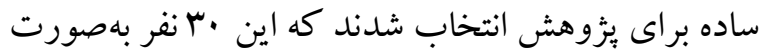

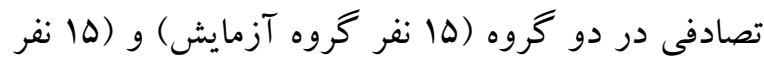
ISI- كواه) جاى داده شدند. برسشنامه سبك هوريت
آموزش بجهها براى بذيرش مسئوليت در درون خانواده روش بسيار مطلوبى براى آماده كردن آنها در بذيرش بدر درئ وظايف و مسئوليتهاى بىشمارى است كه در بيرون از

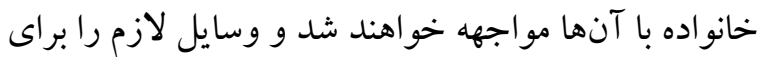
استقلال آنها فراهم مى كند. براى يكك كودكك كه اكنون

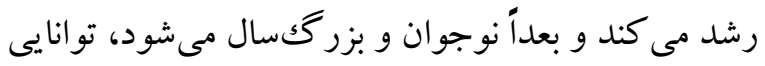
در توفيق مسئوليتهاى اجتماعى خارج از خانواده به فرصت براى تجربه كردن مشاركت ارزشمندى احترام به

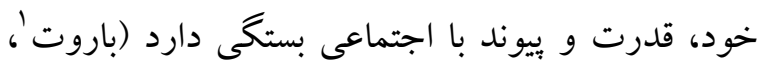

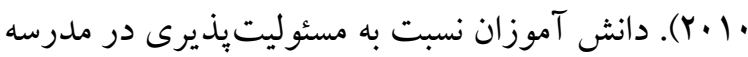
بايد خود آكاهى كسب كند و קجكونگى كمك كردن به يكديخر را ياد بحيرند تا بتواند در موقعيتهاى مختلف كائ مسائل بين فردى خود را حل كنند (كلاسر به • بr). مسئوليت يذيرى به معنى متعلق بودن انتخاب ها به خو دمان

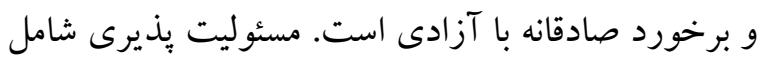
ملاحظه كردن ديخران و سرزنش نكردن آنان بابت مشكلات شخصى نيز است (شارف"، 1999). مسئوليت فرايندى است كه فرد بايد از اولين سالهاى كودكى آن را آموخته تا با وظايف متعددى كه در دوران هاى مختلف زندگى روبه رو مى شود مسئولانه برخورد كند. مسئوليتيذيرى افراد در هر جامعهاى، يكى از ارزشهاى آن جامعه محسوب مى شود و از شاخص هاى مهم سلامت روان محسوب مىشود (رمضانى ديسفانى، •9"1). مهدوى و همكاران (Yar|) در يُزوهشى با عنوان بررسى اثربخشى آموزش مسئوليتيذيرى بر عزتنفس دانش

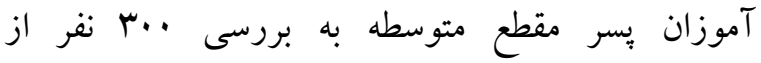

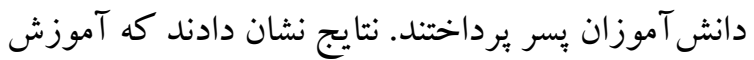

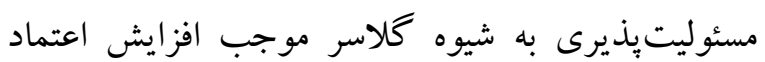

\footnotetext{
. Barewet

. Glaser

3 .Shurff
} 
رضايتبخش بوده است. در يثوهشهاى انجام شده در

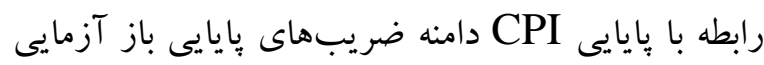
براى هر يك از مقياسهاى آن از • •ه براى مقياس همدلى (Em) تا • •/ · براى مقياس خو يشتندارى (Sc)

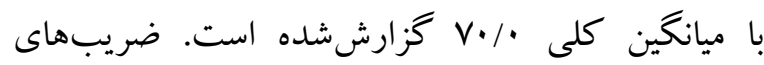
همسانى درونى در مقياس خودباورى (Sa) با • • كمترين همسانى و در مقياس خودشكوفايى با • لهاني بيشترين همسانى درونى را نشان داد (عاطف وحيد،

. (1rq.

روند جلسات اثربخشى كه براى دانش آموزان بهصورت هر جلسه ه\& دقيقه بر گزار گرديد به شرح زير است: جلسه اول، اين جلسه، جلسهاى توجيهى بود كه ضمن معارفه، اهداف آموزشى و قوانين جلسات بيان گرديد، همجينين در اين جلسه بيش آزمون نيز اجرا گرديد. جلسه دوم، تعريف خودآكاهى، تعريف و مقايسه خود آنس واقعى و خود ايده آل، ارائه تكليف جلسه سوم، مرور تكليف جلسه قبل و ارائه بازخورد. توضيح در رابطه با خود گويى و بررسى تفاوت

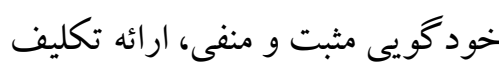
جلسه جهارم، مرور تكليف جلسه قبل و ارائه بازخورد. تعريف كنترل خود، بيان ييشنيازهاى مربوط به كنترل

$$
\text { خود. ارائه تكليف }
$$

جلسه ينجم، مرور تكليف جلسه قبل و ارائه بازخورد. بيان نتايج برخى تحقيقات در مورد اثر خودآكاهى برجنبه هاى مختلف زندگى انسان از جمله خود مديريتى و ... و

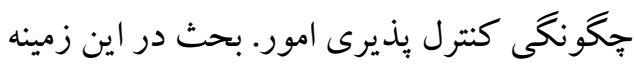
جلسه ششم، تعريف ابراز وجود و بحث گروهى در اين زمينه. ارائه تكليف
6G و مقياس مسئوليتيذيرى روانشناختى كاليفرنيا CPI نمرات بركه بعد از جمع آورى نخهدارى شد و بعد مداخله بر روى گرووه آزمايش صورت كرفت و ورتى بهصورت هفتخى بعد از اتمام جلسات درمان كه ب ا جلسه بود انجام شد، بِ آزمون يعنى بر گههاى برسشنامه دوباره

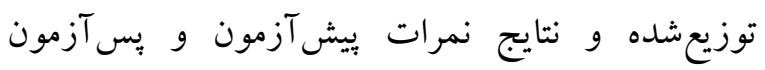
موردبررسى قرار گرفت.

ابز ار در اين مطالعه از دو يرسشنامه زير جهت جمعآورى اطلاعات استفاده خرديد: برسشنامه سبك هويت (SI-6G): اين برسشنامه · F سؤال دارد كه بر اساس جدول زير، بيانگر جهار سبك هويتى است. يس از ياسخدهى به سؤالات، ياسخها را بهصورت

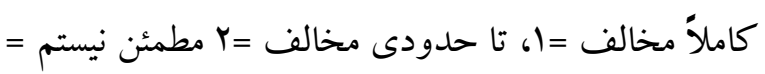
ץ، تا حدودى موافق = F، و كاملاً موافق = ه نمره گذارى كردند. براى ارزيابى و سنجش همسانى درونى برسشنامه سبك هويت، ضريب آلفاى كرونباخ بر روىدادههاى

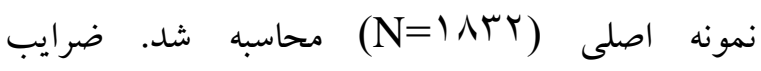

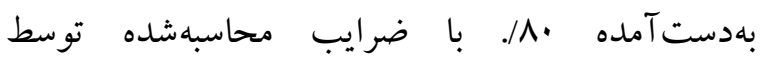
برزونسكى (1994)، وايت و همكارانش (1991) بسيار نزديك هستند.

مقياس مسئوليتيذيوى روانشناختى كاليفرنيا (CPI):

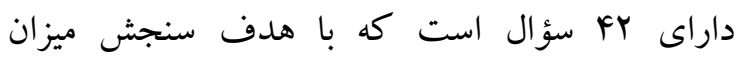
مسئوليت يذيرى افراد بهنجار r ا سال به بالا تهيه شده است و آزمودنىها به صورت موافقم و مخالفم به سؤالهاى

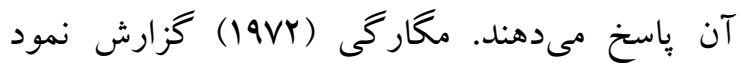

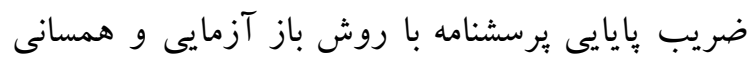
درونى در مقايسه با ساير برسشنامهاى شخصيت كاملاً 
جلسه يازدهم، ارائه داستان زندگى يكك مادر موفق و بررسى و تبادلنظر و درخواست بيان انتقادات. جلسه دوازدهم، مرور مباحث ارائه شد. درخواست انتقاد

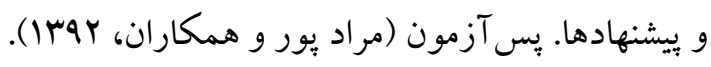

\section{يافته ها}

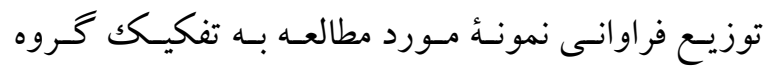

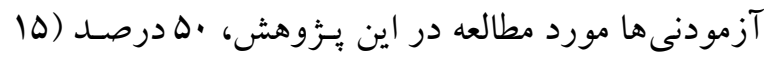

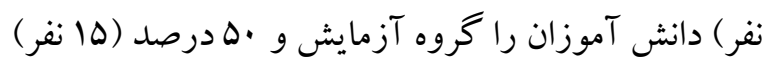
كروه كنترل مىباشند.
جلسه هفتم، مرور تكليف جلسه قبل و ارائه بازخورد. ارائه تكنيك هاى ابراز وجود. ارائه تكليف. جلسه هشتم، ابتدا بازخوردى از جلسه هاى قبل ارائه شد؛ و سبيس بحث در مورد مبانى ابراز وجود، تشخيص رفتارهاى جرات مندانه و بحث و بررسى و تبادل نظر و تمرين عملى اجرا گرديد و تكاليف براى انجام ارائه كرديد. جلسه نهم، مرور تكليف جلسه قبل و ارائه بازخورد. بحث در زمينه بله و نه كفتن و درخو است كردن. ارائه تكليف. جلسه دهم، مرور تكليف جلسه قبل و ارائه بازخورد. بحث در خصوص انتقاد و برخورد مناسب با منتقد و بررسى فوايد و مضرات انتقاد كردن.

جدول شماره 1 :ميانكين و انحراف استاندارد نمرههاى يش آزمون و يسآزمون مسئوليت بذيرى و هويت يابى

\begin{tabular}{|c|c|c|c|c|c|}
\hline \multicolumn{2}{|c|}{ يس آزمون } & \multicolumn{2}{|c|}{ بيش آزمون } & & \multirow[b]{2}{*}{ كروه } \\
\hline انحر اف استاندارد & ميانگين & انحر اف استاندارد & ميانكين & & \\
\hline $10 \cdot r r$ & $|r \&| \cdot V$ & YN/IF & $F V / 110$ & آزمايش & \multirow[t]{2}{*}{ هويت } \\
\hline$\cdot 1 / 9$ & $1 . / 110$ & $99 / 14$ & $\cdot 1 / 110$ & كنترل & \\
\hline$Y F / M$ & $q 4 / 1 F q$ & $94 / 1$. & $r \cdot / I r F$ & آزمايش & \multirow[t]{2}{*}{ مسئوليتيذيرى } \\
\hline$r \mu / 19$ & $r \cdot / 1$ rg & $9 \vee / \Lambda$ & $\Lambda V / I M F$ & كنترل & \\
\hline
\end{tabular}

اطلاعات جدول فوق نشان مىدهد كه ميانگين نمره مسئوليت يذيرى گروه آزمايش در بيش آزمون · · در گروه كنترل برابر IMF/AV است. در مورد ميانگين نمره مسئوليت يذيرى افراد گروه آزمايش در يس آزمون

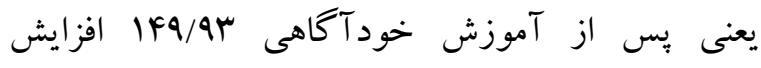
قابلتوجهى نموده است و اين نمره از · • بيش آزمون به سو/9 إ در بس آزمون رسيده است؛ اما

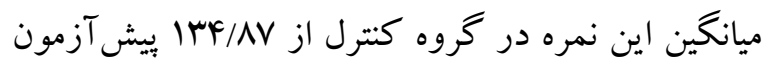

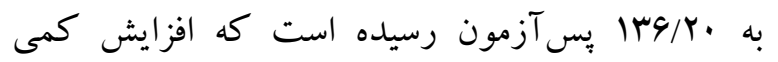

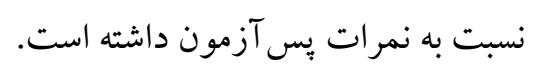

اطلاعات جدول فوق نشان مىدهد كه ميانگين نمره هويت يابى كروه آزمايش در بيش آزمون IO/FV

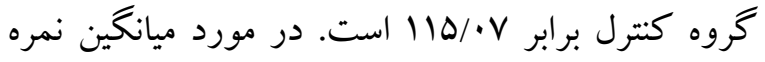

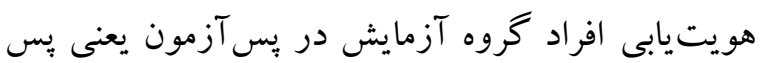

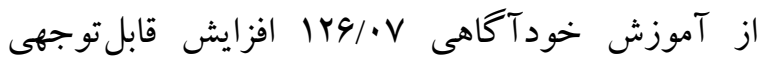

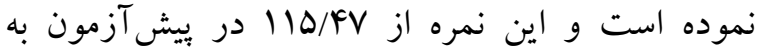

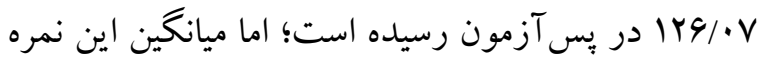

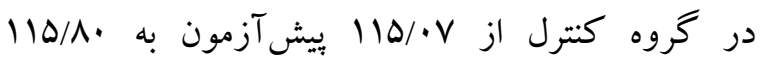
يس آزمون رسيده است كه افزايش ناجيزى نسبت به نمرات بـ آزمون داشته است. 
فاصلهاى بوده است، از آزمون پيارامتريك تحليل كوواريانس جهت تحليل دادهها استفاده شد. 1- آموزش خود آكاهى بر هويت يابى دانش آموزان مؤثر

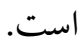

بهمنظور بررسى اثربخشى آموزش خودآكاهى بر

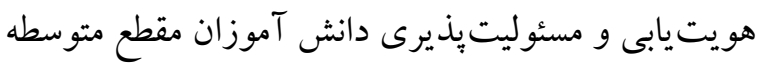
دوم، با هدف تعديل اثر بيشآزمون بر نمرههاى بس آزمون، از تحليل كوواريانس استفاده شد. همجِين با توجه به اينكه توزيع متغيرهاى يزوهش در بيش آزمون

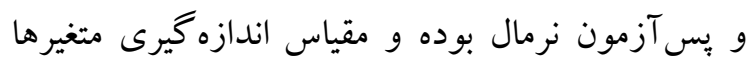

\begin{tabular}{|c|c|c|c|c|c|c|}
\hline توان & معنادارى سطح & $\mathbf{F}$ & $\begin{array}{c}\text { ميانكين مجذورات } \\
\text { (MS) }\end{array}$ & $\begin{array}{c}\text { درجه آزادى } \\
(d f)\end{array}$ & $\begin{array}{c}\text { مجموع مجذورات } \\
\text { (SS) }\end{array}$ & منبع \\
\hline$p q q /$. & $\ldots /$ & $\Delta V I / Y q$ & . DN/YMAY & 1 & $. \Delta N / Y I A Y$ & ييش آزمون \\
\hline \multirow[t]{3}{*}{ ror/. } & $\cdots \Delta / \cdot$ & $|q| / q$ & GMF/NQ. & 1 & GTF/ND. & كروه \\
\hline & & & IrI/Ar & TV & TVD/YYIV & خطا \\
\hline & & & & $r$. & pqrars,... & مجموع \\
\hline
\end{tabular}

ييش آزمون افزايش داشته است. ازاينرو مىتوان نتيجه

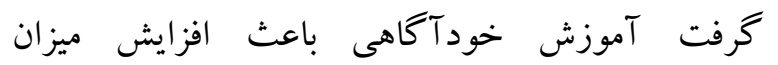
هويت يابى دانش آموزان شده است. مقدار مجذور را نيز نشان مىدهد كه ه r درصد واريانس هويت يابى دانش آموزان از طريق آموزش خود آكاهى، تبيين مىشود. - آموزش خودآكاهى بر مسئوليتيذيرى دانش آموزان مؤثر است.
جنانكه در جدول شماره V مشاهده مىشود F محاسبهده براى اثر بيش آزمون ry/OVI (ازلحاظ آمارى معنادار است) .به بيان ديكر نمرههاى بس بـ آزمون تحت تأثير نمرههاى بيش آزمون قرارگرفته است؛ اما اثر

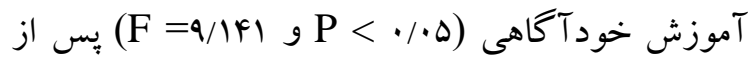
تعديل ميانخين هاى دو گرووه بر اساس نمره ييش آزمون، از لحاظ آمارى معنادار است. ملاحظه ميانگينهاى دو كروه نشان مىدهد كه نمره يس آزمون آزمودنىها هم در گروه آزمايش و هم گروه كنترل نسبت به نمرات

جدول شماره ه: نتايج تحليل كواريانس درخصوص آموزش خودآكاهى بر مسئوليت بذيرى

\begin{tabular}{|c|c|c|c|c|c|c|}
\hline توان & معنادارى & $\mathrm{F}$ & $\begin{array}{c}\text { ميانكين مجذورات } \\
(M S)\end{array}$ & $\begin{array}{c}\text { درجه آزادى } \\
(d f)\end{array}$ & مجموع مجذورات (SS) & منبع \\
\hline$\cdot \cdot v / \cdot$ & 9491. & $19 . / \%$ & FGT/DA & 1 & FGY/DA & يِش آزمون \\
\hline $\mid f \gamma /$. & . F. $/$ & $99 N / 4$ & VFI/IFET & 1 & VFI/IFET & كروه \\
\hline
\end{tabular}




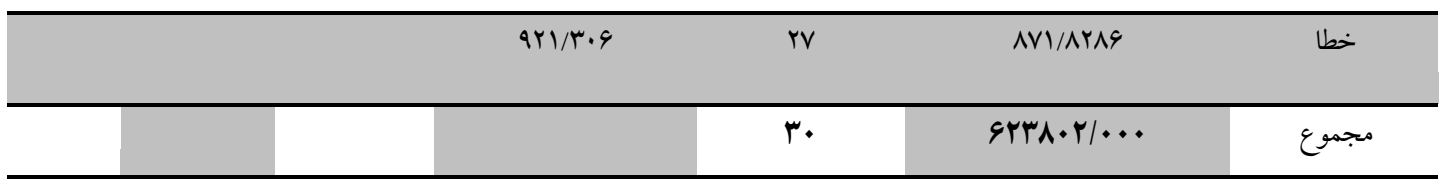

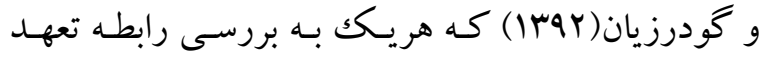
هويت با سبكك هاى بردازش هويـت، سـوء مصـرف مـواد

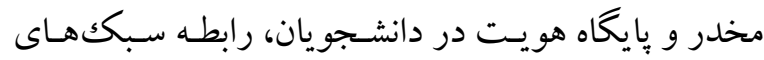
هويـت و رشـد اخلاقى بـا مســوليت بـــيرى دانشـجويان برداختند همسو و همخوان است. همجينين نتايج تحقيـق بـا

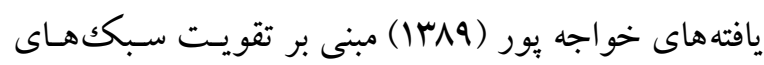
هويت، همسو است. در تبيين يافته فوق مىتوان كفت، بديدهى نوجوانى با اين يرسش اساسى همراه است كه من كيستم، اين برسش كه جند سال ادامه خواهد يافت. درواقع مسئله اين است كه جِكونه مى شود كه هر فردى نه مانند كذشتخان و نه مانند

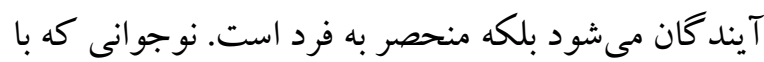
اين يرسشها روبهرو است مىداند كه به زودى بايد مسئوليت زندگى خويش را بر عهده بخيرد؛ و از خود

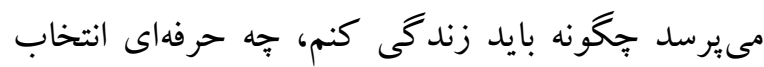

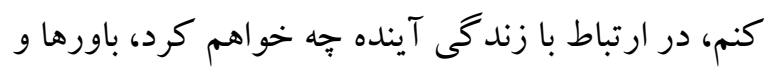

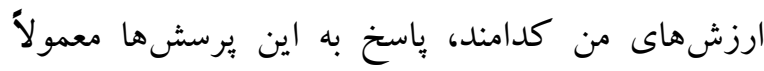
آسان نيست. نوجوان مدتها بس از برسش من كيستم و با كسب اطلاعات و تجربيات متفاوت بالاخره به اين جواب مىرسد كه من خودم هستم. همبِنين در صورت

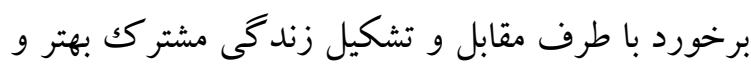
عميق تر با مسائل روبهرو شود. اين خود آكاهى به شخص

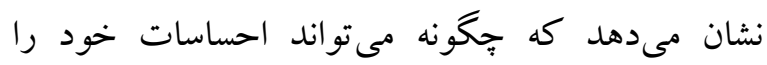
بشناسد، از وجود آنها آكًاه شده و به وقت لزوم آنها را

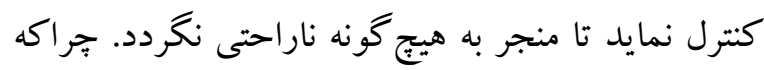

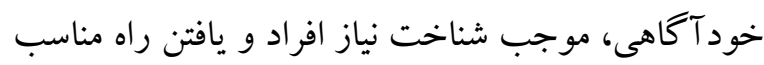

Fنانكه در جدول شماره ^ مشاهده مىشود محاسبهشده براى اثر بيش آزمون •91/ • (از لحاظ آمارى معنادار نيست). به بيان ديخر نمرههاى پِ بس آزمون تحت

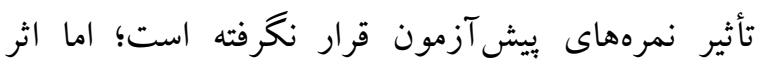

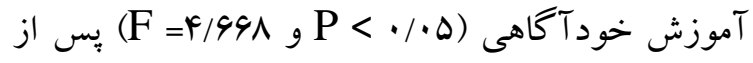
تعديل ميانگين هاى دو گرووه بر اساس نمره بيش آزمون،

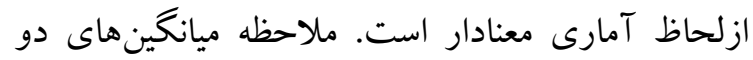
كروه جدول (r) نشان مىدهد كه نمره بـ بسآزمون آزمودنىها هم در گروه آزمايش و هم گروه كنترل نسبت به نمرات بيش آزمون افزايش داشته است. ازاينرو

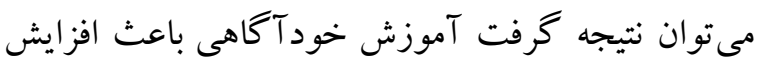
ميزان مسئوليتيذيرى دانش آموزان شده است. مقدار مجذور را نيز نشان مى دهد كه ها درصد واريانس

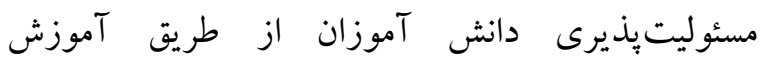
خود آكاهى، تبيين مىشود.

\section{بحث و نتيجه كيرى}

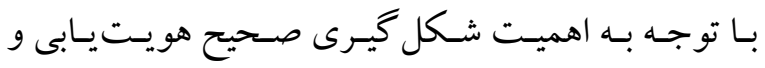

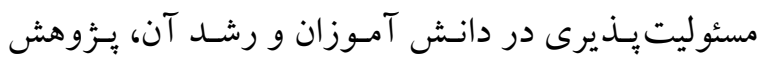

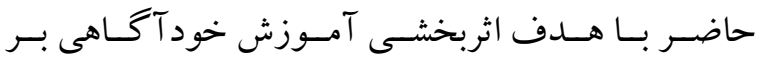
هويت يـابى و مسـئوليت يـــيرى در دانسش آمـوزان مقطع متوسطه سال دوم انجام شد. نتايج آزمون تحليل كوواريانس تكك متغيرى نشان داد كـه آمـوزش خود آكـاهى باعـث افـزايش ميـزان هويـت يـابى

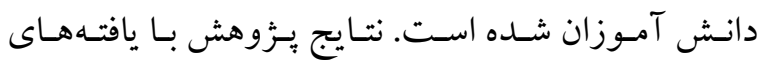

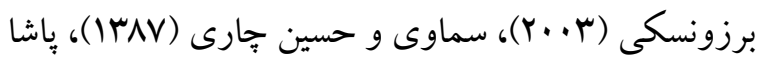


مختلف را به يكديخر بيوند مىدهـد. تولـد يـك كـودك زنســـى كسـانى را كـه مســول يــرورش او هسـتند تغييـر مى دهد و در نتيجـه آنهـا خودشـان فراينـدهاى يـادگيرى جديدى را تجربه مى كنند. تجربـه بـــر و مـادرى معمـولاًا فعاليت هاى بزرگك ترها را به كود كان براى بقيه زندگى هر هر

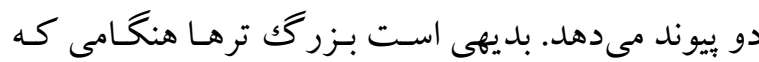

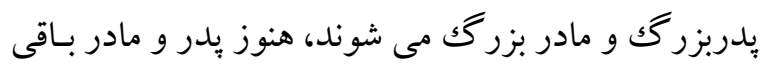

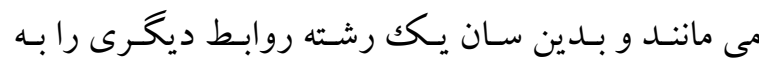

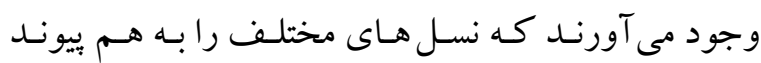
مىدهد

\section{References}

Bersonchecki, R. P. (1992). Assigned chores help teach social personaResponsibility, The Brown university child, and Adolescent Behavior letter.

Berzonsky, M. D., \& Ferrari, J. R. (2009). A diffuseavoidant identity processing style: Strategic avoidance or self confusion? Identity: An International Journal of Theory and Research, 9, 145-158.

Barewet, M. (2010). Teaching your child responsibility. Pagewise. Inc

Berzonesky, M., Cieciuch, J., Duriez, B., \& Soenens, B. (2011). The how and what of identity Formation: Associations between identity styles and Value Orientations. Personality and Individual Differences, 50, 295-299

Berzonsky, M., \& Kuk, S. L. (2005). Identity Style, Psychosocial Maturity, and Academic Performance. Personality and Individual Differences, 36, 235-247.

Bahramie, F. Malekiean, H. \& Abedie, M. R. (2011). The study and comparison of strategies to boost responsibility among guidance school students in Esfahan. Amoozeh Quarterly, (17), 45-48.
براى مواجهه با آنها مىشود. همجِين اهداف زندگى را مشخصتر و واقع بينانهتر نشان مىدهد و ارزش واقعى افراد و مسائل بيرامونشان را نمايان مىسازد. خود آكاهى فر آيند سالم هويت يابى را براى انسان سهل تر مىنمايد، به زندكى او آرامش مىدهد و احساس رضايتمندىاش را رونق مىبخشد. نتايج آزمون تحليل كوواريانس تكك متغيرى همبحنين نشان داد كه آموزش خودآكاهى باعث افزايش ميزان مسئوليتيذيرى دانش آموزان شده است. با يافتهاى

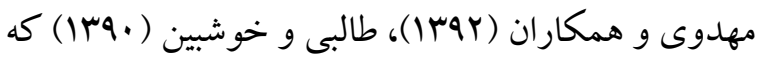
هر يكك به بررسى اثربخشى آموزش مسئوليتيذيرى بر عزت نفس دانش آموزان بـر مقطع متوسطه،

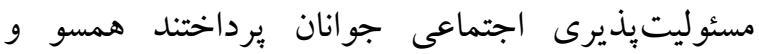

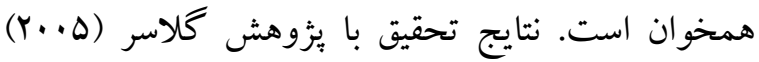

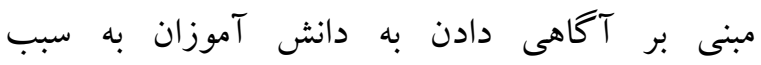

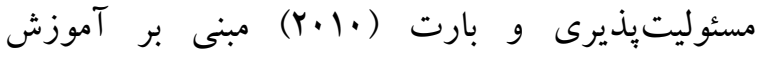

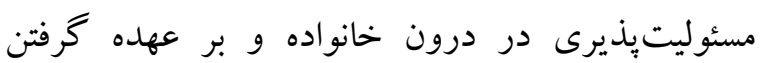
مسئوليت هاى متعدد همسو است. در تبيين اين يافته مىتـوان گفـت، خود آكَاهى مسى توانـد نسوعى احسـاس مســوليت يـــيرى و ايجـاد نظـم از طريـق

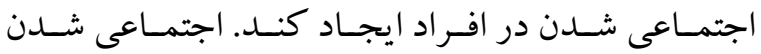
فرايندى است كـه طلى آن كود كك نـاتوان بـه تـدريج بـه

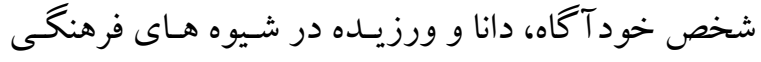

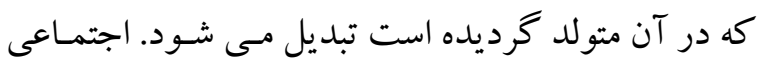

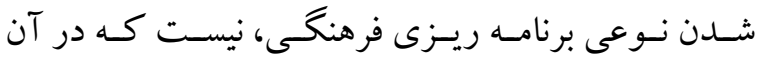

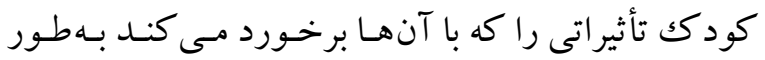
انفعـالى جـذب نمايــد. حتـى كـودكى نـوزاد نيازهــاو خواست هايى دارد كه بر رفتار كسانى كه مسـئول مراقبـت

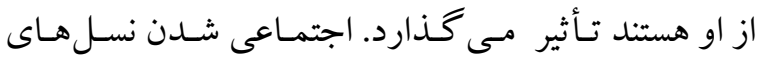


Glaser, V. (2005). Schools without Failure. Translated by: Sadeh, H. 4th edition. Tehran: Roshd Publication.

Jokar, B. Hosaincharie, M. \& Mehrparvar, A. (2014). Prediction social accountability based on identity styles among students of Shiraz university, Culture in Islamic university, 10(4), 17-18.

Kajehpour, Z. (2010). The study of the relationship of intelligence, self-respect and economic status with accountability. MA thesis in general psychology, Islamic Azad University, Ahvaz branch.

Kalat, J. (2013). Physiological psychology. Translated by Seyyed Mohammadi, Tehran, Ravan publications. (date of publication in the original language 2008)

Kaye, M. P. \& Fifer, A. M. (2007). Cognitive links between fear of failure and perfectionism. Journal of Rational-Emotive \& CognitiveBehavior Therapy, 25, 237-252.

Jenaabadi, H \& Dehbashie, A. (2014). Investigating the Role of Identity Styles in Predicting Responsibility and Academic Self-regulation of Third Grade Male High School Students in Zahedan. Intemational Joumal of Social Sciences \& Education, 4,968-977.

Kloomok, S. \& Cosden, M. (1994). Self- concept in children with learning disabilities: the relationship between global self-concept, academic discounting, nonacademic selfconcept andperceived social support. Learning disability quarterly, 17, 140-153.

Mahdavie, A. Anaeti, M. S. \& Nesie, A. (2013). The study of the effect of instruction of accountability on self-respect among boy students of high school. New findings in psychology. 17(2),117-132.

Moharrie, F. Soltaniefar, A. Rezaie Ardanie, A. Modaress Grvie, M. Atesheanpanjeh, S. Soltaniefar, A. (2010). An investigation into the relationship between child attachment concept and teenage attachment with identity basis among the youths within the age range of 11 to 18. Principles of mental health. 18(4), 692-701.
Moradpour, J. Mearie, M. R. Aliabadie, S. \& Abbaspour, S. (2013). The effect of instruction of self awareness and self expression on compatibility and self-respect among mothers of the mentaly retarded children. The scientific quarterly journal of the faculty of midwifery and nursing of Birjand medical sciences university. 10(1), 42-53.

Mousavie, F. (2009). The effect of instruction of life skills on reduction of stress and raising accountability among male addicts.

Pasha, G. \& Godarzeean, M. (2013). The relationship of identity styles and moral growth with responsibility in students.

Ramzanie Desfani, A. (2012). The effect of teaching accountability based on Glasser's method on raising identity crisis of high school students of Isfahan. MA thsis in counseling, Isfahan University, Faculty of psychology and education.

Sagebfar, M. (2003). Deadly identities, Amin Maaloof, translator: Morteza Saqeb far, Tehran, Quqnoos.

Samavi, A. \& Hosaincharie, M. (2008). Misuse of norcotics and the place of identity among students. Iranian Psycholosists quarterly, $5^{\text {th }}$ year, 20(3), 323-332.

Sayd Mohammadi, Y. (2014). Educational psychology, $8^{\text {th }}$ edition. Ravan Publications.

Sharf, R.(1996).Theories of psychotherapy and counseling.Newyork: Intemational thomson pub.

Talebi, A. \& koshbean, Y. (2011). Social accountabilityof the youths. Social sciences quarterly, 59(3), 207-241. 